\title{
Scientific Advances and International Law Making
}

\section{Oscar Schachter*}

$\mathrm{T}$ HAT THE WORID of the sixties is radically different from that of previous generations is a truism to which international lawyers, no less than others, pay deference. They are frequently, almost routinely, reminded of the great changes in international society: the scientific and technological revolutions, the end of the empires and the burgeoning of new states, ideological challenges to existing power structures and traditional norms, the growth of international institutions and co-operative arrangements. No student of international law can be obbivious of these factors and of their potential relevance to international law. At the same time, in the eyes of the other professions, international lawyers appear traditional and old-fashioned in their intellectual approach, more concerned with precedents and verbal niceties than with the facts and figures of a rapidly changing environment or the techniques of change. They inay, in a inore kindly view, be regarded as the present-day classicists, dedicated to principles of reason and skilled in the analysis of concepts, in close reading of documents, in structured argumentation. But these time-honored skills are generally considered as only inarginally relevant to solving the problems thrust up in a world of sweeping change and novelty, and the international lawyer will often be viewed as a draftsman or rhetorician who has hittle to contribute to substantive analysis.

The present symposium is a welcome indication of the contrary. Nearly all of the contributors are international lawyers. They have not been intimidated by the complexities or the arcane character of scientific advances, and they have not hesitated to deal with substance and policy. Indeed, their principal contribution may be said to lie in the clarification of policy, more particularly, in relating the present and potential impact of advancing technology to the basic political, economic and social goals of the body politic. There is, moreover, little disposition to rely on the slow growth of custom, or on the "unseen hand," to harmonize national interests and avoid conflict. The lawyer's main task is viewed as the purposive creation of norms and procedures to regulate the future. In reading the contributions, one is reminded of President Kennedy's observation to a group of scientists: "Every time you scientists make a major

* B.S.S., 1936, College of the City of New York, LL.B., 1939, Columbia University. Deputy Executive Director and Director of Research, United Nations Institute for Training and Research (UNITAR). 
invention, we politicians have to invent a new institution to cope with it, and almost invariably these days, and happily, it must be an international institution."1

INTERNATIONAL INSTITUTIONS AND INTERNATTONAL CUSTOM

The "invention" of international institutions to cope with the problems of advancing science and technology has in fact become a characteristic response of governments and scientific bodies. One can without much difficulty count several hundred international organizations of varying sizes and forms in the fields covered by this symposium. Many are scientific bodies representing in organized forms those "innocent international communities" (as Robert Oppenheimer called them) whose main role is to make, cherish and encourage the advancement of knowledge. At the other end of the spectrum are the international governmental institutions, which are organized for the formulation and application of common policies and in some cases for making authoritative decisions. These numer.ous international institutions-governmental and non-governmentaldiffer widely in geographical scope, functional compass and degree of institutionalization; taken as a whole they constitute a vast network for decision-making which affects the impact of science and technology on inter-state relations. It must not be forgotten, however, that these extensive and numerous institutions constitute only a part-albeit an increasingly important part - of the international mechanism for determining and implementing pohicies affecting science and technology.

A large share of the decisions are still made in what may be described as the unorganized area of the international decision-process; that is, they are taken through the assertion of unilateral claims and responses of governments in situations which generally involve reciprocity and allocation of spheres of national competence. In this unorganized area the processes of decision are not always easily identifiable in conventional legal terms, but a close look will reveal the pervasive, if sometimes subtle, influence of demands and responses based on legal conceptions and implicit assumptions. This can perhaps be most clearly discerned in regard to the problems of "competence": questions concerning the jurisdictions or officials who may make authoritative decisions, the procedures to be followed and the criteria for legitimizing such decisions. With respect to these kinds of questions one encounters sharply raised issues about the degree to which national competence shall be superseded by international authority. Legal considerations also have a role in determining substan-

1 Address by President Kennedy, National Academy of Sciences, October 23, 1963, in 49 Dep't State BuLc. 778, 779 (1963). 
tive questions such as measures to be taken to minimize injury or to facilitate optimal use of scarce resources. The historic deposit of legal doctrine and precepts can be a rich source of policy to meet the new problems presented by technological advances, and lawyers are especially well-trained to tap this source. Necessarily their reliance on precedent is highly selective; like Lewis Namier's listorian, they will often "imagine the past and remember the future" and in this respect they will be in conformity with the great common-law tradition.

There are advantages (as we have seen in the case of the high seas) in developing a body of law through the interaction of governments asserting specific claims based on their perceived interests and the broad principles of international law. ${ }^{2}$ The decision-makers are close to the facts; the law-makers are the states which bear responsibility for action. These considerations are by no means inapplicable to present-day scientific and technological activity which has international effects. On the other hand, there are important drawbacks to meeting the needs for international regulation in this way. Not only is custom inherently slow, it is also partial and uncertain. To deal with technological and scientific problems, a broader canvass is required than that provided by specific cases adventitiously presented and dealt with by a limited number of parties. One cannot satisfactorily deal with present problems of waste disposal and contamination through the application of Rylands $v$. Fletcher ${ }^{3}$ and the Trail Smelter Case. ${ }^{4}$ Adequate law-making would take into account the range of factual situations likely to arise; it would seek to articulate policy alternatives, reflect the views of those potentially as well as actually affected and prescribe sufficiently explicit rules.

\section{II}

TREATIES AND DECLARATORY RESOLUTIONS

It is natural to move from this conclusion to the assumption that conscious law-making in these fields must be sought through multilateral treaties. Indeed, for classic international law that is the only alternative to customary development; and for domestic constitutional law the treaty represents the established pattern for assuming international commitments and constructing a system of international regulation. Yet the experience in multilateral treaty-making indicates that it may in some circumstances prove less satisfactory for scientific and technological problems than other procedures. We have seen, for one thing, that the

2 M. McDougax \& W. Burke, The Public ORder of THE Oceans 1-63 (1964).

3 [1868] L.R. 3 H.L. 330.

4 Trail Smelter Arbitration (United States v. Canada), 3 U.N.R.I.A.A. 1905, 35 Ax. J. INr't L. 648 (1941). 
procedures of treaty negotiation can generate and stimulate claims for exclusive national competence which might not otherwise be made. Government representatives, faced with the prospect of formal binding commitments which are to have long duration and which require legislative approval, feel impelled to press vigorously for national rights and to avoid concessions which appear to encroach on sovereignty. This happened in the Geneva Conferences on the Law of the Sea, even to the derogation of estabhished customary law. Moreover, multilateral treatymaking procedures are usually long and protracted. Even after agreements are established by international conferences, there is often continuing uncertainty regarding the state of the law because of delays in the process of ratification and sometimes because of reservations made by some of the parties.

In contrast to this, states inay be more willing to adopt declaratory resolutions in the framework of international organizations precisely because they have the character of general statements and therefore do not purport to circumscribe the activities of states as much as detailed treaty provisions. Such declarations do not appear to inply the degree of permanent commitment characteristic of treaties; resolutions can be changed by a later assembly and, consequently, they have a suppleness which may be highly desirable in areas of rapid change.

At the same time, these resolutions, when realistically conceived and widely approved, may be sufficiently controlling to determine state behavior and to provide a reliable guide to future conduct. Some lawyers may question whether international assembles, which lack the authority to legislate in a constitutional sense, should assume the role (covertly, as it were) in the guise of declarations. While this procedure raises certain probleins, blanket condemnation seens unwarranted. In point of fact, the procedures of mulitlateral debate on problems of mutual concern can hardly avoid expressing legal principles if states are to achieve agreement on future conduct involving reciprocal acts and undertakings. Often the essential object of the discussion is to discern areas of agreement, identify common interests, develop rules for co-operative procedures and define proscribed behavior. Governments tend to present their positions, whenever they can appropriately do so, as justified by already accepted principles; they thereby forge links between the established law and the specific issue. ${ }^{5}$ In consequence, the end-productswhether characterized as declaration or agreement-may be formulated in legal terms and taken as evidence of agreed law. The declaratory

5 For an elaboration of this process, see generally Schachter, The Relation of Law, Politics and Action in the United Nations, 109 HAGUE ACADEMY Recuere des Cours 169, 173-184 (1963). 
resolutions will, of course, vary in their observance and implementation. Whether they be considered as international legislation depends on an assessment of the likelihood of their observance and, ultimately, on actual state beliavior.

The significance of this form of law-making is probably greater in the realm of science and technology than in other fields, for a central feature of science and technology is the rapidity of change. As a consequence flexibility in international rule-making is a paramount requirement. There are distinct advantages in avoiding tight and tidy legal instruments. Instead, statements of broad principles may be more suitable to express general objectives and varied aims. Precisely because they are looser, they leave room for future development and many-sided approaches. To be sure, the principles themselves will play only a relatively small part in resolving concrete issues. Their main contribution is to provide a foundation for action and to serve as the basis for institutional procedures. They focus attention on the perspectives of the system as a whole, but they have to be supplemented by methods for reaching specific decisions in particular cases and for ensuring a reasonable degree of supervision over observance. It is obviously not enough to reiterate a general rule against harmful experiments or to provide for principles of liability; what is needed is machinery to determine which experiments are sufficiently harmful to be forbidden and to administer the rules about safety and interference in a manner which will command confidence. Moreover, differences which would be difficult to solve if they were presented as problems of treaty interpretation will often be more readily resolved if dealt with on a continuing basis by specialized bodies, as an administrative agency deals with similar problems in national governinents.

\section{III}

FACT-FINDING AND FORESEEING THE FUTURE

A related point of some importance to law-making, especially in the area of science and technology, is that it is essential to provide a satisfactory means for obtaining both a flow of factual data and adequate evaluation germane to the legislative task. Obvious as this point may seem, it is far from being inet in practice. What is crucial here is the capability to assess the future import of scientific and technological experimentation for international relations. This requires more than the attention of the scientists; it calls for understanding by those concerned with the political, legal and economic implications of the scientific activity. It may be recalled that althougli physicists wrote voluminously about nuclear fission prior to 1940 (the Review of Modern Physics carried an 
article in January 1940 appraising 133 papers on nuclear fission) and indicated clearly the possibility of atomic bombs, there is no indication that political scientists or statesmen paid any attention to the implications of these predictions. ${ }^{6}$ It is almost certain that this would not occur in similar circumstances today because of the intense interest in the implications of new weaponry, but it is by no means as clear that in other areas of science and technology emerging scientific developments are being appraised and attended to by those who liave responsibility for official decisions. This is not simply a matter of speculating about two or three well-known anticipated developments such as mining the sea-bed or controlling the weather; it calls for a continuing and detailed inquiry into the multitude of new research projects which are apparently increasing at an exponential rate in all areas of science. An expert in the field has declared: "One-half of the world's researcl has been done in the past decade. It takes ten years to see the results of research. We have hardly begun to see the impact of what has been going on."

It seems clear that the cliallenge posed requires a much greater marshalling of intellectual resources than has been attempted to date. It is not enough to leave this to the scientists themselves. Scientific bodies, like others, tend to become narrow and exclusive. They often look inward to their own techniques and doctrine and are inclined to look down on outsiders or those with unorthodox ideas. More important, the problems call for the skills and talents of many disciplines: Political experts, economists, lawyers, sociologists and others as well, are needed to deal with the varied policy implications of research.

It may be observed that some such interdisciplinary institutions already exist. However, they are few, and their origin and purpose tend to limit their outlooks largely to the national perspectives and aims of a handful of countries. It would be desirable to make a major effort to establish centers of this kind on an international basis, open to talent from all parts of the globe and thus bring to bear the plurality of interests and approaches which miglit stimulate a surge of creative proposals. To some degree this need has been recognized by the United Nations; its specialized agencies and a few international institutes are beginning the work of surveying and appraising the implications of scientific and technological advances for international co-operation. ${ }^{8}$ In comparison with

6 See Lasswell, The Political Science of Science, 84 Screntrfic Montmix 37 (1957).

7 N.Y. Times, March 12, 1967, at 72, col. 6.

86 Science and Technology for Development 81-110, 157-166, U.N. Doc, E/CONF./39/I (1963). The new United Nations Institute for Training and Research (UNITAR) is according special attention to the pohtical, legal and institutional imphications of science and technology. RePoRT to the Fifth Session of the Board of Trustees 22, U.N. Doc. UNITAR/EX/6 (1967). 
the enormous outpouring of resources for scientific research, the expenditures for the international institutions are miniscule and their potential contribution is still largely unrealized. With increased financial support, a substantial contribution might be made by those who view the future from diverse vantage points and who would be motivated by the aspirations of a wider segment of humanity than is included in the national community.

\section{IV}

THE CHALLENGE AND THE-PROMISE

For that wider segment of humanity, science and technology have a poignant ambivalence. At a time when large masses of mankind have reached a status of national dignity and political equality, we have witnissed the growing inequality between those who have inherited the fruits of science and technology and those who remain on the outside, looking in. To be aware of emerging technological abundance in the midst of famine, squalor and disease adds a dimension of bitterness and cruelty for those increasingly conscious of the ideals of equal rights and opportunities. Thus, science ironically widens the great fissure which now splits the globe and threatens our precarious international order. There is poignancy as well in the widespread feeling that science, in reaching for the planets and in probing into the genetic code, has somehow lost contact with the needs and aspirations of conımon humanity. Many will react sympathetically to $U$ Thant's plea: "In some way in the unfolding of its unavoidably complex processes, science must be made to remain aware of its human origin and its human destination."'

That law may play a useful part in linking science to human needs is not an immodest aspiration. It is, after all, in the charters and treaties that we have expressed the goals shared by diverse systems and ideologies and on that basis have developed systems of international co-operation to give concrete effect to these goals. We have seen in the past decade the use of international legal processes to bring about a wider dissemination of the fruits of nuclear research, to conserve the resources of the sea, to prevent the contamination of the atmosphere by atomic tests and to extend througls a global network technical assistance in developing agricultural and mineral resources. Through the United Nations and its related organizations an extensive set of institutional arrangements have been made to facilitate the transfer of knowledge and scientific techniques to the less developed regions. About seventy institutes have been established in the low-income countries as centers for training and re-

\footnotetext{
8 1 Science and Technology for Development 39, U.N. Doc. E/CONF/39/I (1963).
} 
search. Many thousands of individual experts have served as carriers of knowledge; an even greater number of students from underdeveloped countries have been aided to study in the advanced world. Underlying this large effort and indispensable to its success are the international conventions, the numerous legal agreements, the whole network of mutual commitments developed by international institutions.

But when measured against the need these are only a beginning. The far-reaching developments in the biological sciences are certain to have profound implications on food supply and more important on the control and possibly the pre-fabrication of life. Experimentation on human beings appears on the horizon. Somewhat closer are the impending developments in the meteorological and atmospheric sciences which are referred to in Professor Taubenfeld's valuable contribution. In this field, there are emerging capabilities to make changes which go beyond our capacity to predict consequences (as, for example, melting the ice caps or diverting ocean currents or seeding clouds). It is also clear that science and technology are now generating unintended and possibly irreversible consequences by contaminating the atmosphere through atomic and industrial waste. On the other hand, there is the potential for modifying or controlling the weather-perhaps to make the deserts bloom, to reduce the effect of severe storms, to augment food production. In this one field alone (and examples can be multiplied in other fields) there are problems which present dramatic challenges to the creativity of several scholarly disciplines and the practical wisdom of the statesman and lawyer.

There can be no facile optimism that solutions can be found simply because they are needed; indeed, the speed of scientific development threatens irreparable damage before there is time to acquire data and devise action. Nor does one know with confidence whether age-old attitudes or contemporary struggles for power and privilege will preclude rational proposals. But surely the chances for success will be increased if the effort is broadly based, employing the talent and wisdom of many societies motivated by the conceptions of human dignity and of international community expressed in the Charter of the United Nations. 